\title{
Techno-Economic Evaluation of Solar Tunnel Dryer for Drying of Basil (Ocimum sanctum)
}

\author{
C.M. Badgujar*, O.S. Karpe and S.R. Kalbande \\ Dept of UCES Dr.PDKV, Akola, India \\ *Corresponding author
}

\section{A B S T R A C T}

\section{Keywords \\ Basil leaves, Drying time, Moisture content, Solar tunnel dryer and drying rate \\ Article Info \\ Accepted: \\ 04 June 2018 \\ Available Online: \\ 10 July 2018}

\begin{abstract}
A solar tunnel dryer installed at Ramakrishna Agro. Vegetables \& Food Product Kodoli, was evaluated. Its performance for Basil leaves drying and also its techno-economic analysis was carried by different indicators such as Net Present Worth (NPW), BenefitCost ratio (B:C) and Payback Period. The maximum temperature of $61^{\circ} \mathrm{C}$ was recorded at $13: 30 \mathrm{~h}$ in solar tunnel dryer during the drying process which was $40.49 \%\left(36.3^{\circ} \mathrm{C}\right)$ higher than the maximum ambient temperature at the same time. On an average, a total drying time of 12.5 hours were required for solar tunnel dryer to reduce the moisture content of Basil leaves from initial value of 1011.11 percenton dry basis (d.b) to a final moisture content of 33.33 per cent (d.b) while the open sun drying required on an average 15.5 drying hours to obtain same level of moisture content. The Net Present Worth, Costbenefit Ratio and Payback period for solar tunnel dryer were Rs. 62,894/-, 1.11 and 7 Month 2 Days, respectively.
\end{abstract}

\section{Introduction}

Basil (Ocimum Sanctum) is a popular culinary and medicinal herb from ancient time until now also called as holy basil or Basil. The uses of basil are varied and plentiful in its fresh form in food preparation; it is used with vegetables, meat, fish, sauces, stews, dressings, herbal teas, liqueurs, and mixed drinks i.e. flavouring from their strong spicy aroma But it is basil's medicinal properties, rather than its culinary value, that extend the herb's uses and it has innumerable medicinal applications ranging from treating mundane coughs and colds effectively to rendering poisoning inactive (Rajput., 2012). It has also other important medicinal properties such as antioxidant, anti-inflammatory, antiviral or anti-microbial properties. Basil is considered to be adaptive balancing different process in the body and helpful for adapting to stress. It contains Vitamin A, C, and minerals like calcium, zinc, iron as well as chlorophyll and many others. Phytonutrients also enhance the efficient digestion and use of nutrients from the uses of food and other herbs (Bhatejaet al., 2012).

Basil powdered as many benefits as follows, relieve stress, acts as an adaptogen, bolsters immunity, enhances stamina, provide support during the cold season, promote healthy 
metabolism, natural immune modulator. Basil powdered is also used for the preparation of tea which is caffeine free and safely consumes up to six times a day. For more benefits increase the ratio of Basil powder to water steep longer. The powder also found to cause a reduction in fasting blood sugar and postprandial glucose level in patients. The basil plant is scarce during offseason, which necessitates good preservation, also the plant is highly perishable and has to be preserved against deterioration and spoilage so drying is proposed.

Drying is the most widely used primary method of food preservation. The green color of Basil leaves is due to the chlorophyll. The most common change occurs in the green colour vegetables during the thermal processing is the conversion chlorophyll to the pheophytin, causing a colour change from bright green to olive-brown, which is undesirable to consumer for a green vegetables, pre-treatment prior to the drying can aid the chlorophyll to retain during the drying operation (Kalbande et al., 2016). Traditionally, the food products are dried by spreading in open sun in a thin layer. Though this method is economical and simple, it has the drawbacks like; no control over the rate of drying, non-uniform drying, chances of deterioration due to exposure of products against rain, dust, storm, birds, rodents, insects and pests which results in poor quality of dried products (Rathore et al., 2010; Assefa et al., 2010). In open sun drying the losses of valuable properties of Basil take place, so retain that valuable property tunnel drying is preferred (Kumar et al., 2017).

\section{Materials and Methods}

The experiment was carried at solar tunnel dryer installed at Ramakrishna Agro. Vegetables and Fruit Products, Kodoli, TalPanhalla, Dist- Kolhapur, By CAET DR. P.
D. K. V. Akola. Its technical specifications are given in Table 1.

\section{Study of drying characteristics}

The drying mechanism depends on simultaneous heat and mass transfer phenomenon and factors dominating each process determined the drying behavior of the product (Dulawat et.al., 2012; Garg et. al 2012). The drying rates were computed from the experimental data and drying characteristics curves i.e. moisture ratio $(\mathrm{db})$ vs. time, drying rate vs. time and moisture content $(\mathrm{db})$ were plotted.

\section{Determination of moisture content}

The initial moisture content of the sample was determined by the hot air oven drying method as recommended by (Ranganna S. 1986). Samples and weighed using electronic weighing balance of least count $0.01 \mathrm{~g}$. The samples Basil were placed in a hot air oven at $70 \pm 0.5^{0} \mathrm{C}$ for $12.00 \mathrm{~h}$ and Following formulae were used (Bala, 2016).

$$
\text { M.C. }(\mathrm{db}) \%=\frac{\left(\mathrm{W}_{1}-\mathrm{W}_{2}\right)}{\left(\mathrm{W}_{2}\right)} \times 100
$$

Where,

$\mathrm{W}_{1}=$ Weight of the sample before drying,

$\mathrm{W}_{2}=$ Weight of bone dried sample

\section{Determination of moisture ratio}

The Moisture ratio of the produce was computed by following formula (Chakraverty, 1988).

Where,

$$
\text { MoistureRatio (M.R.) }=\frac{\left(M-M_{e}\right)}{\left(M_{0}-M_{e}\right)}
$$

$\mathrm{M}=$ Moisture content (db), per cent

$\mathrm{M}_{\mathrm{e}}=\mathrm{EMC},(\mathrm{db})$, per cent

$\mathrm{M}_{0}=\mathrm{IMC},(\mathrm{db})$, per cent 
The drying rate of product sample during drying period was determined as follows (Chakraverty, 1988).

Dry ing rate $\left(D_{R}\right)=\frac{\Delta W}{\Delta t}$

Where,

$\Delta \mathrm{W}=$ Weight loss in one $\mathrm{h}$ interval (gm/100gm bdm min.)

$\Delta \mathrm{t}=$ Difference in time reading $(\mathrm{h})$

\section{Drying efficiency (n)}

The drying efficiency of solar tunnel dryer is the ratio of heat gained to the heat input. The heat input was calculated by considering total solar radiation incident in aperture area of solar tunnel drier during total drying hours in the day. (Prasad et al., 2006)

1. $\%=\frac{(M \times 2)}{\left(I_{A C} \times A \times t\right)} \times 100$

Where,

$\mathrm{M}=$ Mass of water evaporated, $\mathrm{kg}$

$\lambda=$ Latent heat of vaporization, $\mathrm{MJ} \mathrm{kg}^{-1}$

$\mathrm{I}_{\mathrm{ac}}=$ Total solar radiation, $\mathrm{MJ} \mathrm{m}^{-2}$

$\mathrm{A}=$ Collector area $\mathrm{m}^{2}$

$\mathrm{t}=$ Time, sec.

\section{Economic analysis of solar tunnel dryer}

Economic analysis of solar tunnel dryer was calculated by using economic indicators Viz., Net present worth (NPW), the benefit-cost ratio $(\mathrm{B} / \mathrm{C}$ ratio) and payback period.

The following assumptions/considerations were taken for carrying out an economic analysis of solar tunnel drying system. The area of the solar tunnel dryer was $18.0 \mathrm{~m}^{2}$, capacity of the solar tunnel dryer for basil leaves was $25 \mathrm{~kg}$ batch $^{-1}$, the dryer produce $2.5 \mathrm{Kg}$ dried product of basil leaves, the initial cost of the basil leaves Rs. $25 \mathrm{~kg}$., discounting rate was assumed to be 10 per cent as compared to bank lending rate of interest, cost dried product of basil powder was Rs. $850 \mathrm{Kg}$, the annual repair and maintenance cost was Rs.10,000 considering replacement of UV sheet after 3 years and expenditure towards painting etc.

\section{Results and Discussion}

Testing of solar tunnel dryer was carried at no load and full load condition on clear sunny days (Fig. 1 and 2).

\section{No load testing of a solar tunnel dryer}

The variation of temperature, relative humidity of different locations inside the solar tunnel dryer with corresponding ambient temperature, relative humidity was recorded to evaluate the performance of solar tunnel dryer at no load condition during the winter season (Oct.2014).

Figure 3 showed that during the monsoon season, the maximum peak temperature inside the solar tunnel dryer with respect to time achieved its peak value at 13:00 h. was found to be $62^{\circ} \mathrm{C}$ with corresponding ambient temperature, relative humidity and solar radiation of $34.7^{\circ} \mathrm{C}, 27$ per cent and 950 $\mathrm{W} / \mathrm{m}^{2}$, respectively. It was observed that the maximum temperature inside the solar tunnel dryer was found to be $62^{\circ} \mathrm{C}$ followed by top $\left(62^{\circ} \mathrm{C}\right)$ and bottom $\left(61^{\circ} \mathrm{C}\right)$ tray at 13:00 h.

Figure 4 showed that minimum relative humidity inside the solar tunnel dryer was found to be 10 per cent and its peak value at 13:00 $\mathrm{h}$ and maximum relative humidity inside the tunnel dryer was found to be 38 per cent and it was achieved at 9:00 $\mathrm{h}$

\section{Full load testing of a solar tunnel dryer}

The samples of the basil leaves were loaded in a thin layer on trays over racks in the solar 
tunnel dryer. The drying of these samples was continued till the moisture content reached to EMC of the selected products on $\mathrm{db}$. The drying experiments were carried out in monsoon season in the month of October.

Figure 5 revealed that the maximum temperature inside the solar tunnel dryer achieved its peak value $61^{\circ} \mathrm{C}$ at $13: 30 \mathrm{~h}$ of the day-3 corresponding to top $61^{\circ} \mathrm{C}$ and bottom $55^{\circ} \mathrm{C}$ with corresponding ambient temperature $36.3{ }^{\circ} \mathrm{C}$ and relative humidity 30 per cent and solar radiation $940 \mathrm{~W} / \mathrm{m}^{2}$, respectively. The minimum temperature $32^{\circ} \mathrm{C}$ was achieved at 9:00 $\mathrm{h}$ with corresponding top $40^{\circ} \mathrm{C}$ and bottom $32^{\circ} \mathrm{Cwith}$ corresponding ambient temperature $30.1^{\circ} \mathrm{C}$ with ambient relative humidity53 per cent and solar radiation 640 $\mathrm{W} / \mathrm{m}^{2}$. Thus the temperature inside the solar tunnel dryer varied from $32^{\circ} \mathrm{C}$ to $61^{\circ} \mathrm{C}$.

From figure 6 revealed that the minimum relative humidity inside the solar tunnel dryer achieved its peak value 12 per cent at 15:30hr of the day corresponding to the ambient temperature $32.2^{\circ} \mathrm{C}$, ambient relative humidity 25 per cent with solar radiation $600 \mathrm{~W} / \mathrm{m}^{2}$. The maximum relative humidity inside the solar tunnel dryer was found to be 28 per cent at 9:00 $\mathrm{h}$ of the day with corresponding ambient temperature $30.1^{\circ} \mathrm{C}$, ambient relative humidity 53 per cent and solar radiation $640 \mathrm{~W} / \mathrm{m}^{2}$.

\section{Drying characteristics of basil leaves in open sun drying and solar tunnel dryer}

The drying characteristics of basil leave samples in natural convection solar dryer was studied and compared with open sun drying. The different drying characteristics in terms of moisture content per cent (db) drying rate (gm $/ 100 \mathrm{gm} \mathrm{bdm} \mathrm{min)} \mathrm{and} \mathrm{moisture} \mathrm{ratio} \mathrm{were}$ studied.

\section{Drying of basil leaves in STD and OSD}

From figure 7 and 9 revealed that the average moisture content per cent (db) of Basil leaves inside and outside sample was reduced from 1011.11 to 33.33 per cent and 33.33 per cent from $(\mathrm{db})$ in $12.5 \mathrm{~h}$ and $15.5 \mathrm{~h}$ in solar tunnel dryer and open sun drying, respectively. Similarly, it was observed that the maximum moisture removal had taken place from 1011.11 to 262.96 per cent and 400per cent (db) up to $8 \mathrm{~h}$ during the first day of drying.

Table.1 Technical specification of STD

\begin{tabular}{|l|l|}
\hline \multicolumn{1}{|c|}{ Particulars } & \multicolumn{1}{c|}{ Specifications } \\
\hline Aperture area, $\mathbf{~ m 2}$ & 24.25 \\
\hline Width of dryer, $\mathbf{m}$ & 3.00 \\
\hline Length of dryer, $\mathbf{m}$ & 6.00 \\
\hline Drying tray area, $\mathbf{m} \mathbf{2}$ & $2.5(1.6 \mathrm{~m} \times 1.6 \mathrm{~m})$ \\
\hline Number of trays & 05 on each trolley \\
\hline Number of trolleys & 2 Nos., $(1.67 \times 3.12 \times 1.2 \mathrm{~m})$ \\
\hline Height of tunnel, $\mathbf{m}$ & 2.0 \\
\hline Plastic cover, UV stabilized & $200 \mu \mathrm{m}$ \\
\hline Chimney & 2 Nos., $\varnothing 0.15 \mathrm{~m}, \mathrm{H}=0.75 \mathrm{~m}$ \\
\hline Fresh air vent area, m2 & 0.05 \\
\hline $\begin{array}{l}\text { Exhaust Fan, single phase, } \\
\mathbf{4 0} \mathbf{W p}, \mathbf{1 4 0 0} \mathbf{~ r p m}\end{array}$ & 1 Nos, Brushless AC \\
\hline Door & $1.80 \mathrm{~m} \times 0.75 \mathrm{~m}$ \\
\hline
\end{tabular}


Table.2 Overall efficiency of STD

\begin{tabular}{|l|l|l|l|l|l|}
\hline $\begin{array}{l}\text { Sr. } \\
\text { No. }\end{array}$ & Sample & $\begin{array}{l}\text { Total } \\
\text { drying } \\
\text { time, } \\
\text { (sec) }\end{array}$ & $\begin{array}{l}\text { Avg. moisture } \\
\text { removed,(kg) }\end{array}$ & $\begin{array}{l}\text { Avg. Solar } \\
\text { Radiation, } \\
\left(\mathbf{k J} / \mathbf{m}^{2}\right)\end{array}$ & $\begin{array}{l}\text { Efficiency, } \\
(\mathbf{\%})\end{array}$ \\
\hline $\mathbf{1}$ & Basil & 45000 & 88 & 31950 & 34.58 \\
\hline
\end{tabular}

Table.3 Economic analysis of STD

\begin{tabular}{|l|l|r|}
\hline $\begin{array}{l}\text { Sr. } \\
\text { no. }\end{array}$ & Description & Basil leaves \\
\hline $\mathbf{1}$ & Initial investment $(\mathrm{Rs})$ & 55000 \\
\hline $\mathbf{2}$ & Annual use no. of batches & $80(25 \mathrm{Kg})$ \\
\hline $\mathbf{3}$ & Cost of raw material $\left(\mathrm{Rs} \mathrm{yr}^{-1}\right)$ & @ $25 \mathrm{Kg}$ \\
& & 50,000 \\
\hline $\mathbf{4}$ & Cost of labour for drying $\left(\mathrm{Rs} \mathrm{yr}^{-1}\right)$ & $10,000.00$ \\
\hline $\mathbf{5}$ & Operation and maintenance cost $\left(\mathrm{Rs} \mathrm{yr}^{-1}\right)$ & 3000.00 \\
\hline $\mathbf{6}$ & Total dried product $(\mathrm{kg})$ & 100 \\
\hline $\mathbf{7}$ & Total cost of finished product & 85000 \\
\hline & Economic Indicators & \\
\hline $\mathbf{A}$ & Net present worth, Rs & 62894.23 \\
\hline $\mathbf{B}$ & Benefit- cost ratio & 1.11 \\
\hline $\mathbf{C}$ & Payback period & 7 month 2 day \\
\hline & & \\
\hline
\end{tabular}

Fig.1 Schematic view of a solar tunnel dryer

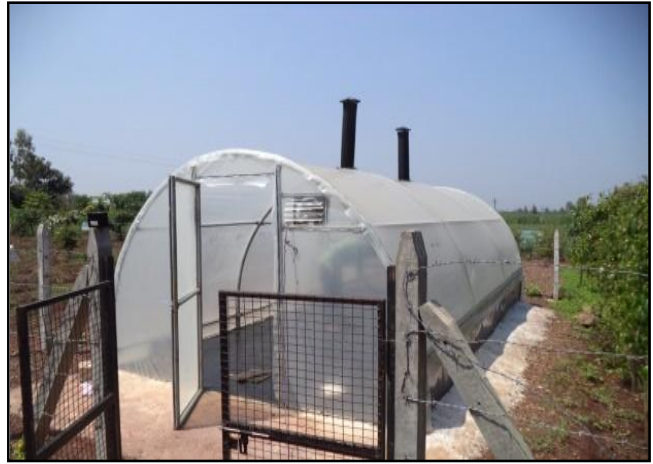

Fig.2 Process flow chart of Basil

The fresh product was chosen for the experiment of Basil and the following process are done.

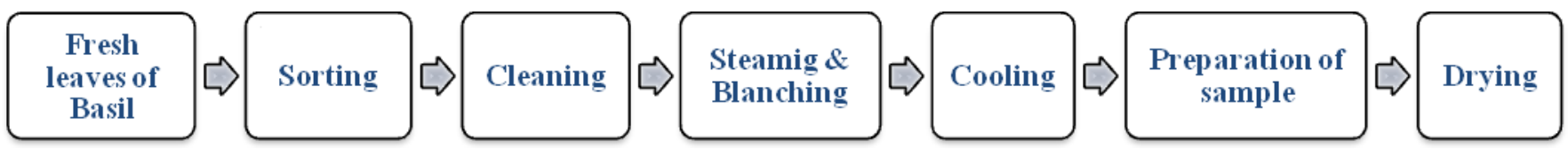




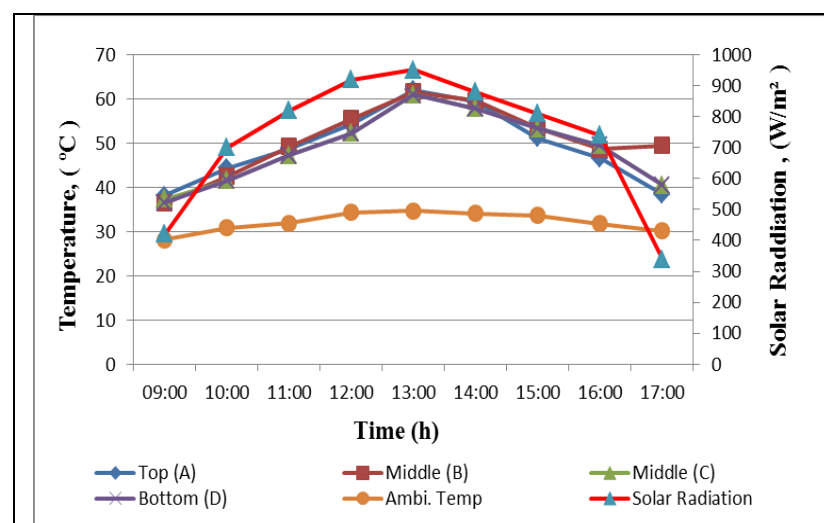

Fig 3: Average temperature variation during no load test in STD

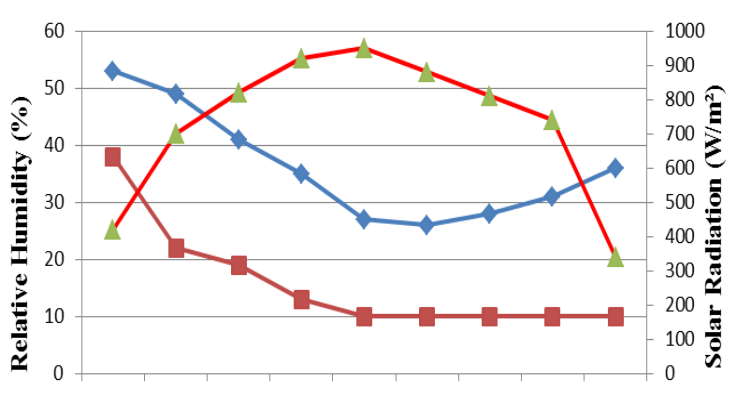

$\begin{array}{lllllllll}09: 00 & 10: 00 & 11: 00 & 12: 00 & 13: 00 & 14: 00 & 15: 00 & 16: 00 & 17: 00\end{array}$

Time (h)

$\rightarrow$ RHO (\%) $\rightarrow$ RHI (\%) $\rightarrow$ Solar Radiation

Fig 4: Relative Humidity variation during no load test in STD

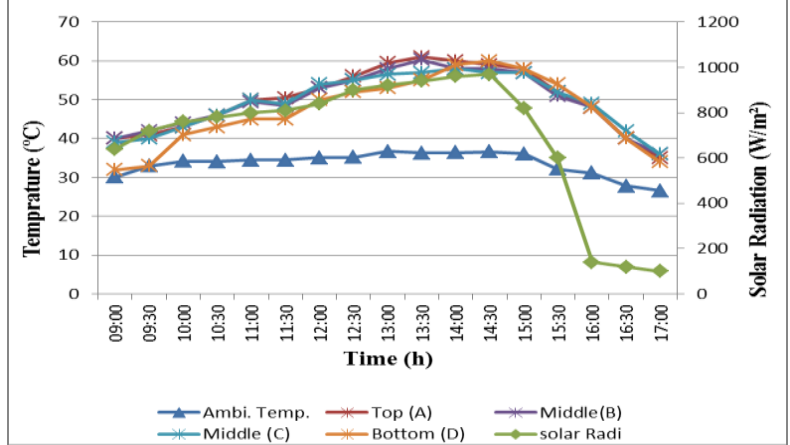

Fig.5: Average temperature variation during full load test in STD

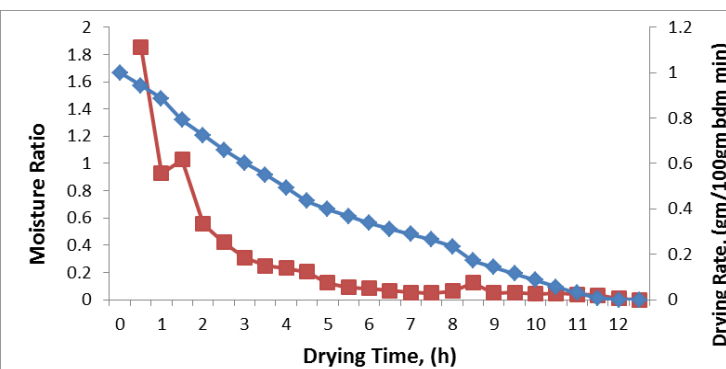

$\rightarrow-\mathrm{DR} \rightarrow \mathrm{MR}$

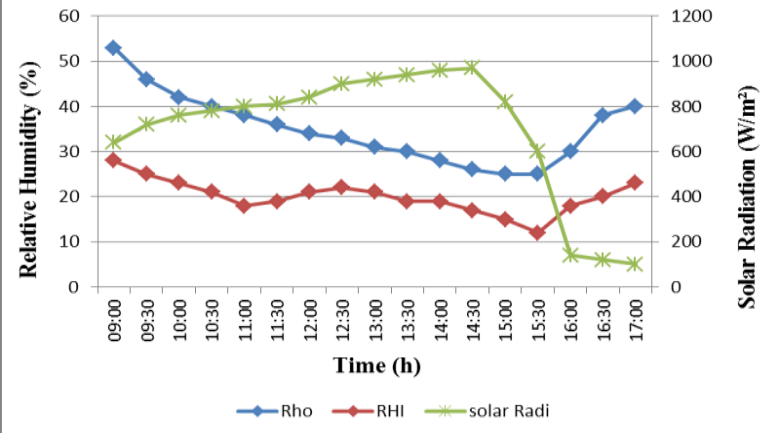

Fig. 6: Relative humidity variation during full load test in STD

Fig.7: Variation of moisture ratio and drying rate of Basil Fig.8: Variation of Moisture Content of basil leaves in STD leaves in STD

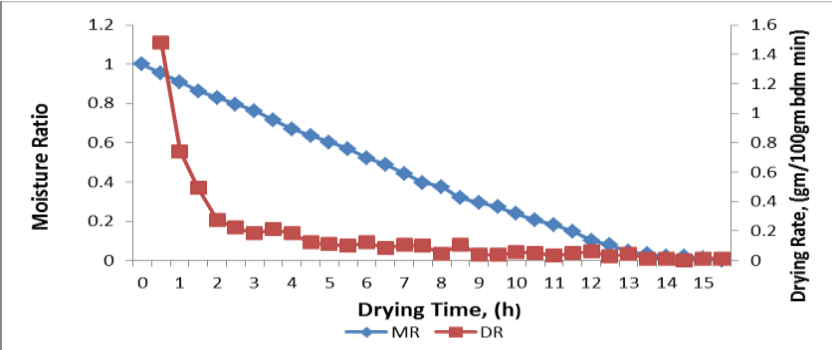

Fig.9: Variation of moisture ratio and drying rate of Basil leaves in OSD

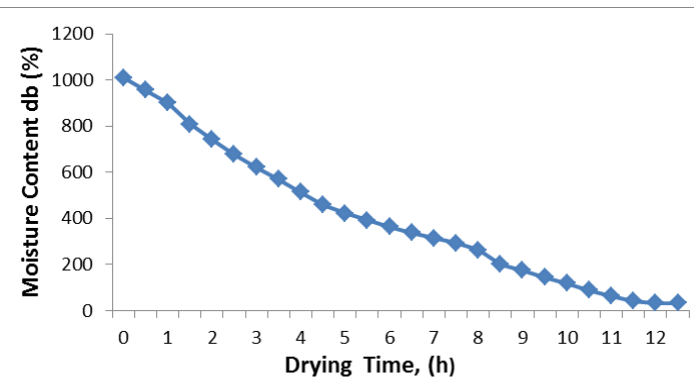

$\leadsto \mathrm{MC}$

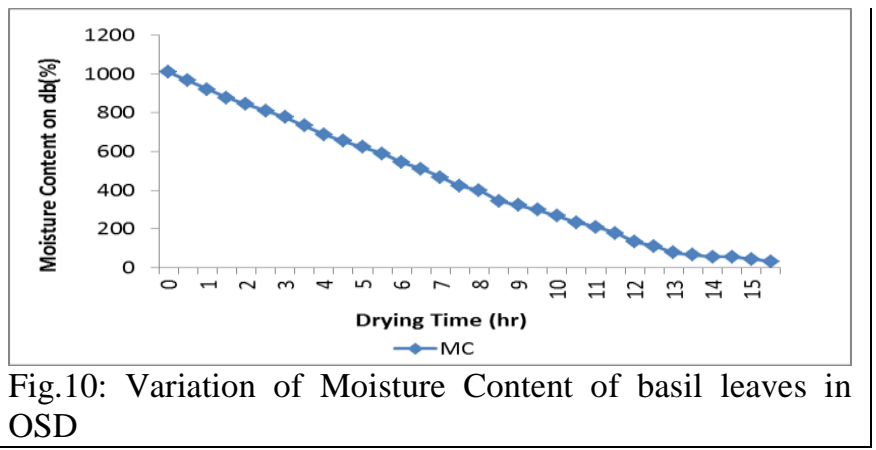


From figure 8 and 10 revealed that the drying rate varied from 1.8518 to $0.010288 \mathrm{gm} / 100 \mathrm{gm} \mathrm{bdm}$ min and 1.4814 to $0.01194 \mathrm{gm} / 100 \mathrm{gm}$ bdm min for drying of basil in solar tunnel dryer and open sun drying, respectively. The average drying rate was found to be 0.1234 and $0.10582 \mathrm{gm} / 100 \mathrm{gmbdm}$ min corresponding to average moisture ratio of 0.3977 and 0.4431 for STD and OSD, respectively.

\section{Drying efficiency ( $(\mathbf{y})$}

Overall efficiency for drying of basil leaves in STD was determined by considering the heat gained and heat utilized by the product in STD.

\section{The overall efficiency of a solar tunnel} dryer

The overall efficiency of solar tunnel dryer based on experimental data was calculated by considering the total moisture evaporated associated with heat input and heat gain byproduct. The results obtained from overall efficiency of basil leave dried in solar tunnel dryer are depicted in Table 2.

It is revealed from Table 2 that the overall efficiency of Basil samples dried in solar tunnel dryer in monsoon season was found to be 34.58 per cent. The overall efficiency is associated with total drying $h$ and heat input by solar energy in STD. The total drying h, avg. moisture removed and avg. heat input for basil sample was found to be $12.5 \mathrm{~h}, 88 \mathrm{~kg}$, $31950 \mathrm{~kJ} / \mathrm{m}^{2}$, respectively

\section{Economics of solar tunnel dryer for drying Basil Leaves}

The economic feasibility of the solar tunnel dryer for the drying of above sample was calculated by considering the initial investment of the dryer, average repair and maintenance cost, cost of raw material and selling price of the material after drying. Based on the study average parameter were calculated for economic analysis of different samples depicted in Table 3.

It is concluded from the results that at no load test, the avg. temperature and relative humidity during daytime in the STD were $50.67^{\circ} \mathrm{C}$ and 15.77 per cent and in OSD was $32.16{ }^{\circ} \mathrm{C}$ and 36.22 per cent, respectively. It was observed that in full load test avg. temperature and relative humidity during daytime STD were $47.58^{\circ} \mathrm{C}$ and 19.70per cent in OSD was $32.32^{\circ} \mathrm{C}$ and 33.41 per cent in the month of October. Solar tunnel drying took $12.5 \mathrm{~h}$ for Basil to bring down the moisture content from 1011.11 to 33.33 per cent $(\mathrm{db})$ and $16 \mathrm{~h}$ under open sun drying. The overall drying efficiency of basil leaves and was found to be 34.58 per cent. The benefitcost ratio, net present worth and payback period for basil leaves were found to be 1.11.Rs. 62894.23 and 7 months 2 day.

\section{References}

Assefa, Ayyappan S and Mayilsamy K (2010). Solar Tunnel Drier With Thermal Storage For Drying of Copra", Proceedings of the 37th National and 4th International Conference on Fluid Mechanics and Fluid Power Dec 16-18, 2010, IIT Madras, Chennai, India.

Bala B K (2016) Drying and Storage of Cereal Grains. doi: 10.1002/978111 9124207.

Bala B K, Hussain M D and Mondol M R (1999). Experimental Investigation of Solar Tunnel Drier for Drying of Pineapple. Journal of the Institution of Engineers, Bangladesh, Agricultural Engineering Division, 26(4): 37-44 (1999).

Bhateja S, Arora G (2012). Therapeutic 
benefits of holy basil (tulsi) in general andoral medicine: a review. IJRAP Vol: 3(6).

Chakraverty A (1988). Post-harvest technology of cereals, pulses and oil Seed. New Dehli, Oxford and IBH Pub. Co. Pvt. Ltd., Pp. 33-39

Dulawat M S, Parakhia A M, Kunjadia B B and Joshi N S (2012). Solar Tunnel Dryer for Rural Area E-ISSN: 2278 179XJournal of Environmental Science, Computer Science and Engineering and Technology Engineering and Technology Research.

Garg, H P, and Kumar R, (2000). Studies on Semi-Cylindrical solar tunnel dryer: thermal performance of collector Applied thermal and engineering. J. Renewable Energy. 20: 115-131.

Kalbande S R (2016). Thin layer drying of sweet neem, basil leaves and moth beans. IJPRET, Vol 4(8): 421-429.
Kumar N M, Nema P (2017). Review on Solar Energy Dryer for Drying the Agricultural Products IJSRD Vol. 5(08).

Prasad J, Prasad A and Vijay V K (2006). Studies on the drying characteristics of Zingiber officinale under open sun and solar biomass (hybrid) drying. International Journal of Green Energy 3(1):79-89: DOI: $10.1080 / 019715205$ 00439526

Rajput K R (2012).Medicinal Uses of Tulsi. Market survey: Oct-2012.

Ranganna, S. (1986) Handbook of Analysis and Quality Control for Fruits and Vegetable Products. Tata McGraw Hill Publishing, New Delhi.

Rathore N S, Panwar N L (2010). Design and development of energy efficient solar tunnel dryer for industrial drying Clean Tech Environ Policy. Doi: 10.1007/s10098-010-0279-3.

\section{How to cite this article:}

Badgujar, C.M., O.S. Karpe and Kalbande, S.R. 2018. Techno-Economic Evaluation of Solar Tunnel Dryer for Drying of Basil (Ocimum sanctum). Int.J.Curr.Microbiol.App.Sci. 7(07): 332339. doi: https://doi.org/10.20546/ijcmas.2018.707.040 